\title{
Scent Marketing - Harnessing the Power of Scents in stimulating senses of Organized Retail Consumers and Employees
}

\author{
K. RAMA MOHANA RAO ${ }^{1} \&$ EDUKONDALA RAO JETTI ${ }^{2}$ \\ ${ }^{1}$ Professor, Department of Commerce \& Management Studies, Andhra University, Visakhapatnam, India \\ ${ }^{2}$ Faculty Member, Department of Business Studies, Ibra College of Technology, Oman
}

\begin{abstract}
Scent' has a tremendous influence on the way people shop and relate to brands. Branding has always been about establishing emotional ties between the brand and the customer. By influencing the senses, brands can establish a stronger and longer lasting emotional connection with the customer and finally be memorable. While research doesn't clearly point to pleasant smells boosting sales, stores are embracing scent marketing as a way to create exciting store ambience. The present study is an attempt to examine the impact of ambient Scent on the customers' and employees' of organized retail stores.
\end{abstract}

Keywords:- Scent Marketing, Ambient Scent, Retail Store, Consumer Behavior, Aroma, odor, Branding, etc.

\section{INTRODUCTION}

"Consumers use all of their senses to experience a brand. The sense of smell emotionally effects humans up to 75\% more than any other sense"

Martin Lindstrom, Brand Sense

In-Store Fragrancing (Ambient Scent Marketing) is the specific use of aromas and fragrances to create an enticing, comfortable and interesting retail, service or display environment. Scent branding is more than just diffusing a pleasant fragrance in a space. It is the art of taking a company's brand identity, marketing messages, targeting audience and matching these with a fragrance that amplifies these branding aspects. Scent marketing revolves around the fact that a human brain is most receptive, and most likely to form, retain, revisit and reinterpret memory, when all five senses are engaged.

The smell of success, for many stores, is now an actual smell. As more shops add odor, the battle for noses is getting intense. This can become highly effective in environments where other sensory triggers, such as the use of lighting, sound and luxurious surroundings combine as brands can establish a longer-lasting emotional connection with consumers.

Ishwar kumar, et.al, (2010) $)^{1}$ investigated the cognitive effects of retail store atmospherics on customer value, store image and patronage intensions. The research revealed that the retail customers are more inclined towards olfactory and tactile factors like air conditioning, ambient odors and soothing store atmospherics.
Hendrik N.J. Schifferstein, et.al., (2011) ${ }^{2}$ conducted a field study at three dance clubs using three scents that are believed to fit the night club environment with an expectation that pleasant scents would increase revenue from drinks, number of visitors and improvement in the visitors mood and evaluation of the club environment as compared to no-scent condition. The three scents used in the experiment were orange, sea water fresh and peppermint. The results revealed that environmental fragrancing is the better solution to get rid of the unpleasant smells in the nightclubs. The study disclosed that pleasant scents stimulated dancing activity which further improved the evaluation of the evening, evaluation of the music as well mood of the visitors.

Tendai, $\mathrm{M}$ and Crispen, C (2009) ${ }^{3}$ in their study used impulsive decision making theory and the consumer decision making model to examine the impact of in-store shopping environment on shoppers' impulsive buying. In the study, out of the factors that were examined atmospheric factors like aroma, music and ventilation were found to be making customers stay for long in a shop and had no direct influence on impulsive buying.

Jean-Charles Chebat and Richard Michon (2003) ${ }^{4}$ conducted a study to test the impact of ambient scents on emotions, cognition and spending of mall shoppers'. The research results revealed that ambient scents help build positive perceptions towards the mall environment and product quality.

H. N. J. Schifferstein and S.T. Blok $(2002)^{5}$ conducted two tests, one to examine if the presence of pleasant ambient scent increased product sales as compared to a no scent retail environment and the other to investigate if ambient scent could function as a signal for products which did not emit that scent but were thematically congruent with it. The research results revealed that the presence of thematic (in) congruency alone might not suffice the need for an odor to affect the sales of a particular product.

Spangenberg, E. R, et.al, $(1996)^{6}$ conducted an olfaction research to study the effect of ambient scent on customers product evaluations and shopping behaviors. It is observed from the study that customers would sense the longer time spent on shopping to be shorter by diffusing ambient scent into the store environment and at the same time the intensity of the scent did not noticeably affect the perception of the customers. The study concluded that a 
store appeals to be more approving, superior, contemporary and unparalleled in scented conditions.

Against this backdrop the current study has been taken up with an objective of analyzing the impact of ambient scent on customers shopping experience and employee behavior at organized retail stores. The following null hypothesis has been set for the study.

\section{Hypothesis I}

$\mathrm{H}_{0}$ - Scent in the retail store is not having positive impact on shopping behavior of the Customers.

\section{Hypothesis II}

$\mathrm{H}_{0}$ - Scent in the retail store is not having positive impact on the behavior of store employees.

The study covers two retail outlets i.e. Big Bazaar and Spencer, for the survey conducted in Vijayawada, Visakhapatnam and Hyderabad cities. Since the universe of the organized retailing is large, convenience sampling technique is used to select the sample units. The size of the sample is 450 customers and 270 employees of the selected retail stores. Likert scale has been used to collect opinions. Analysis of Variance (ANOVA) is applied using SPSS 16.0.

\section{A. Impact of Scent on Customer Shopping Behavior}

$\mathrm{H}_{0}$ : Scent in the retail store is not having positive impact on the shopping behavior of the customers

An attempt was made to extract the opinion of the respondents about the impact of scent on their shopping behavior at organized retail stores. Twelve options, about scents that normally influence behavior of customers were asked to respondents. The results are presented in table: 1 . The mean values of the statements varied between 2.56 and 3.33. The statements 'Scent in the store makes me feel relaxed and comfortable' and 'Scents makes me to visit the store again and again' secured the highest rating with a mean value of 3.33 and 66.53 per cent score respectively. The statement 'I get excited when exposed to the pleasant fragrance in the store', secured second position with a mean value of 3.29 and 65.87 per cent score respectively. The third preference has been given to the statement 'Mild scents makes me feel very positive in shopping' with a mean value of 3.20 and 63.96 per cent score. The statement 'Pleasant scents make me spend more time in the store' secured the least mean value 2.56 and 51.11 per cent score respectively. The standard deviation 0.25 signifies the consistency in respondents' opinion for the statements used in the question.

\begin{tabular}{|c|c|c|c|}
\hline Scent & Score & Mean & $\begin{array}{c}\text { \% to } \\
\text { Max. Score }\end{array}$ \\
\hline Scents play an important role in my store choice & 1404 & 3.12 & 62.40 \\
\hline Scent in the store makes me feel relaxed and comfortable & 1497 & 3.33 & 66.53 \\
\hline Product related or congruent scents accelerates my purchase intention & 1232 & 2.74 & 54.76 \\
\hline Pleasant scents make me spend more time in the store & 1150 & 2.56 & 51.11 \\
\hline Pleasant scents make me purchase more items in the store & 1230 & 2.73 & 54.67 \\
\hline Mild scents makes me feel very positive in shopping & 1439 & 3.20 & 63.96 \\
\hline Pungent smells makes me feel very positive in shopping & 1417 & 3.15 & 62.98 \\
\hline I get excited when exposed to the pleasant fragrance in the store & 1344 & 2.99 & 59.73 \\
\hline Suitable scents contribute to my store satisfaction & 1422 & 3.16 & 63.20 \\
\hline Scents make me to visit the store again and again & 1497 & 3.33 & 66.53 \\
\hline Presence of ambient scent enhances the perceived value of the store & 1482 & 3.29 & 65.87 \\
\hline Ambient scent provokes me to spread positive word-of-mouth about the store. & 1362 & 3.03 & 60.53 \\
\hline
\end{tabular}

Table 1:- Impact of Scent on the Behavior of Customers in Organized Retail Stores Source: primary data 
Comparison of Impact of Scent on customer shopping experience between Male and Female shoppers.

The mean scores of gender wise responses on impact of Scent on customer shopping experience is given in the Table 1.1a followed by ANOVA Table 1.1b.

The mean scores of the sample respondents was found to be 58.97 indicating that the respondents have given considerably less importance to Scent. Further, the average scores for Male and Female are 61.55 and 55.03 respectively.

\begin{tabular}{|c|c|c|c|}
\hline Gender & N & Mean & Std. Deviation \\
\hline Male & 272 & 61.5564 & 12.12076 \\
Female & 178 & 55.0375 & 12.84163 \\
Total & 450 & 58.9778 & 12.80088 \\
& & & \\
\hline
\end{tabular}

Table 1.1a: Scent Impact across Gender of the Customers

Source: primary data

\begin{tabular}{|c|c|c|c|c|c|}
\hline Gender & Sum of Squares & Df & Mean Square & F & Sig. \\
\hline Between Groups & 4572.225 & 1 & 4572.225 & 29.685 & .000 \\
Within Groups & 69001.997 & 448 & 154.022 & \\
Total & 73574.22 & 449 & & \\
& & & & \\
\end{tabular}

Table 1.1b: Comparison of Impact of Scent on Shopping between Male and Female Shoppers (ANOVA)

The Analysis of Variance (ANOVA) was conducted to find out whether there existed any significant difference between Male and Female in their average scores as expressed in the table 1.1a. The result of the ANOVA is given in Table 1.1b. The calculated $\mathrm{F}$ value (29.68) was found to be significant at $5 \%$ level. The results indicated that there existed a significant variation in the perception of Male and Female respondents towards impact of Scent on shopping.
Comparison of Impact of Scent on customer shopping experience on Age of respondents.

The mean scores of age wise responses on impact of Scent on customer shopping experience is given in the Table 1.2a followed by ANOVA Table 1.2b.

The mean scores of the sample respondents was found to be 58.97 indicating that respondents have given considerably less importance to scent. The mean scores of Impact of scent on customers shopping experience were given in Table 1.2a for identified age groups 20-30, 31-45, 45 above. The average scores for respondents of age group 20-30 is 59.48 , for the age group $31-45$ is 59.76 , and for the age group 45 above the average score is 56.07 respectively.

\begin{tabular}{|c|c|c|c|}
\hline Age & N & Mean & Std. Deviation \\
\hline $20-30$ & 196 & 59.4813 & 12.32745 \\
$31-45$ & 173 & 59.7688 & 13.77342 \\
$>45$ & 81 & 56.0700 & 11.43918 \\
Total & 450 & 58.9778 & 12.80088 \\
\hline
\end{tabular}

Table 1.2a: Scent Impact among different age groups of Customers Source: primary data

\begin{tabular}{|c|c|c|c|c|c|}
\hline Age & Sum of Squares & Df & Mean Square & F & Sig. \\
\hline Between Groups & 842.825 & 2 & 421.412 & 2.590 & .076 \\
Within Groups & 72731.398 & 447 & 162.710 & \\
Total & 73574.222 & 449 & & \\
\hline
\end{tabular}

Table 1.2b: Comparison of Impact of Scent on Shopping among different age groups of Shoppers (ANOVA)

The Analysis of Variance (ANOVA) was conducted to find out whether there existed any significant difference among respondents of three age groups as expressed in the table 1.2a. The result of the ANOVA is given in Table 1.2b. The ANOVA result showed that the calculated $F$ value (2.59) was found to be not significant at 5\% level. The results indicated that there exists no significant variation among respondents of different age groups in their average scores on impact of scent on shopping.
Comparison of Impact of Scent on customer shopping experience on Educational qualification of respondents

The mean scores of Educational qualification wise responses on impact of scent on customer shopping experience is given in the Table 1.3a followed by ANOVA Table 1.3b. 
The mean scores of sample respondents was found to be 58.97 indicating that the respondents have given considerably less importance to scent. The average scores for respondents having SSC/Inter qualification is 59.57, for respondents of degree qualification the average score is 60.97 , for respondents having post-graduation and above the average score is 55.89 respectively.

\begin{tabular}{|c|c|c|c|}
\hline Education & N & Mean & Std. Deviation \\
\hline ssc/inter & 109 & 59.5719 & 13.49707 \\
Degree & 194 & 60.9794 & 12.51080 \\
pg\&above & 147 & 55.8957 & 12.12924 \\
Total & 450 & 58.9778 & 12.80088 \\
\hline
\end{tabular}

Table 1.3a: Scent Impact among different Educational groups of Customers Source: primary data

\begin{tabular}{|c|c|c|c|c|c|}
\hline Education & Sum of Squares & Df & Mean Square & F & Sig. \\
\hline Between Groups & 2212.106 & 2 & 1106.053 & .001 \\
Within Groups & 71362.116 & 447 & 159.647 & \\
Total & 73574.222 & 449 & & \\
\hline
\end{tabular}

Table 1.3b: Comparison of Impact of Scent on Shopping among different Educational groups of Shoppers (ANOVA)

The Analysis of Variance (ANOVA) was conducted to find out whether there existed any significant difference among respondents of three educational groups as expressed in the table 1.3a. The result of the ANOVA is given in Table 1.3b. The ANOVA result showed that the calculated $\mathrm{F}$ value (6.92) was found to be significant at $5 \%$ level. The results indicated that there exists a significant variation among respondents of different educational groups in their average scores on impact of scent on shopping.
Comparison of Impact of Scent on customer shopping experience on Occupation of respondents

The mean scores of Occupation wise responses on impact of scent on customer shopping experience is given in the Table 1.4a followed by ANOVA Table 1.4b.

The mean scores of the sample respondents was found to be 58.97 indicating that the respondents have given considerably less importance to scent. The average score for student was 58.70 , for homemakers the average score is 59.80 , for employees the average score is 60.80 , for selfemployed the average score is 56.34 respectively.

\begin{tabular}{|c|c|c|c|}
\hline Occupation & N & Mean & Std. Deviation \\
\hline Student & 126 & 58.7037 & 13.42616 \\
Homemaker & 93 & 59.8029 & 12.57069 \\
Employee & 127 & 60.8005 & 12.42233 \\
Self-employed & 104 & 56.3462 & 12.40297 \\
Total & 450 & 58.9778 & 12.80088 \\
\hline
\end{tabular}

Table 1.4a: Scent Impact among different Occupational groups of Customers Source: primary data

\begin{tabular}{|c|c|c|c|c|c|}
\hline Occupation & Sum of Squares & Df & Mean Square & F & Sig. \\
\hline Between Groups & 1214.969 & 3 & 404.990 & 162.240 & \\
Within Groups & 72359.254 & 446 & 496 & & \\
Total & 73574.222 & & & \\
\hline
\end{tabular}

Table 1.4b: Comparison of Impact of Scent on Shopping among different Occupational groups of Shoppers (ANOVA)

The Analysis of Variance (ANOVA) was conducted to find out whether there existed any significant difference among respondents of different occupational groups as expressed in the table 1.4a. The result of the ANOVA is given in Table 1.4b. The ANOVA result showed that the calculated $F$ value (2.49) was found to be not significant at $5 \%$ level. The results indicated that there exists no significant variation among respondents of different occupational groups in their average scores on impact of scent on shopping.
Comparison of Impact of Scent on customer shopping experience on Monthly Income of respondents

The mean scores of Monthly Income wise responses on impact of scent on customer shopping experience is given in the Table 1.5a followed by ANOVA Table 1.5b. 
The mean scores of the sample respondents was found to be 58.97 indicating that the respondents have given considerably less importance to scent. The average score for respondents having less than 20000 income is 57.00 , for respondents having income more than 20000 but less than 35000 is 59.43 , for respondents having income more than 35000 but less than 50000 is 61.55 , for respondents having more than 50000 is 61.09 respectively.

\begin{tabular}{|c|c|c|c|}
\hline Monthly Income & N & Mean & Std. Deviation \\
\hline$<20000$ & 204 & 57.0098 & 12.95510 \\
$20001-35000$ & 92 & 59.4384 & 12.87034 \\
$35001-50000$ & 73 & 61.5525 & 12.00350 \\
$>50000$ & 81 & 61.0905 & 12.45035 \\
Total & 450 & 58.9778 & 12.80088 \\
\hline
\end{tabular}

Table-1.5a: Scent Impact among different Income groups of Customers

Source: primary data

\begin{tabular}{|c|c|c|c|c|c|}
\hline Monthly Income & Sum of Squares & Df & Mean Square & F & Sig. \\
\hline Between Groups & 1655.095 & 3 & 551.698 & 3.421 & .017 \\
Within Groups & 71919.127 & 446 & 161.254 & \\
Total & 73574.222 & 449 & & \\
\hline
\end{tabular}

Table-1.5b: Comparison of Impact of Scent on Shopping among different Income groups of Shoppers (ANOVA)

The Analysis of Variance (ANOVA) was conducted to find out whether there existed any significant difference among respondents of different income groups as expressed in the table 1.5a. The result of the ANOVA is given in Table $1.5 \mathrm{~b}$. The ANOVA result showed that the calculated $F$ value (3.42) was found to be significant at 5\% level. The results indicated that there exists a significant variation among respondents of different income groups in their average scores on impact of scent on shopping.

Though no significant differences were identified across variables like age and occupation of the respondents, the study revealed significant differences on the identified categorical variables such as gender, education and income. Hence, we reject the null hypothesis.
Comparison of Impact of Scent on Customer Shopping Experience between stores and Cities.

The mean scores of store wise responses with respect to region on impact of scent on customer shopping experience is given in Table 1.6a followed by ANOVA Table 1.6b.

The mean scores of Impact of scent on customers shopping experience with respect to Big Bazaar and Spencer's in the cities of Hyderabad, Vijayawada and Visakhapatnam were given in Table 1.6a. The impact of scent on customers at Big Bazaar is found to be more intense in Vijayawada followed by Hyderabad and Visakhapatnam with average scores 63.06, 62.35 and 60.66 respectively. The impact of scent on customers at Spencer's is found to be more intense in Hyderabad followed by Vijayawada and Visakhapatnam with average scores 59.60, 57.93 and 50.24 respectively.

\begin{tabular}{|c|c|c|c|c|}
\hline Store & City & Mean & Std. Deviation & $\mathrm{N}$ \\
\hline \multirow[t]{4}{*}{ Big Bazar } & Hyderabad & 62.3556 & 11.91843 & 75 \\
\hline & Vijayawada & 63.0667 & 11.54701 & 75 \\
\hline & Visakhapatnam & 60.6667 & 13.00854 & 75 \\
\hline & Total & 62.0296 & 12.16125 & 225 \\
\hline \multirow[t]{4}{*}{ Spencer's } & Hyderabad & 59.6000 & 13.26514 & 75 \\
\hline & Vijayawada & 57.9333 & 12.70726 & 75 \\
\hline & Visakhapatnam & 50.2444 & 10.09970 & 75 \\
\hline & Total & 55.9259 & 12.72201 & 225 \\
\hline \multirow[t]{4}{*}{ Total } & Hyderabad & 60.9778 & 12.64319 & 150 \\
\hline & Vijayawada & 59.3000 & 12.17764 & 150 \\
\hline & Visakhapatnam & 56.6556 & 13.26956 & 150 \\
\hline & Total & 58.9778 & 12.80088 & 450 \\
\hline
\end{tabular}

Table-1.6a: Scent Impact on Customer Behavior across Stores and Cities

Source: primary data 
ISSN No:-2456-2165

\begin{tabular}{|c|c|c|c|c|c|}
\hline Source & Type III Sum of Squares & Df & Mean Square & F & Sig. \\
\hline Corrected Model & $8154.741^{\mathrm{a}}$ & 5 & 1630.948 & 11.069 & .000 \\
\hline Intercept & 1565270.222 & 1 & 1565270.222 & $1.062 \mathrm{E} 4$ & .000 \\
\hline Store & 4191.210 & 1 & 4191.210 & 28.446 & .000 \\
\hline City & 1424.481 & 2 & 712.241 & 4.834 & .008 \\
\hline Store * City & 2539.049 & 2 & 1269.525 & 8.616 & .000 \\
\hline Error & 65419.481 & 444 & 147.341 & & \\
\hline Total & 1638844.444 & 450 & & & \\
\hline Corrected Total & 73574.222 & 449 & & \\
\hline \multicolumn{7}{|c|}{ a. R Squared $=.111$ (Adjusted R Squared $=.101$ ) } \\
\hline
\end{tabular}

Table-1.6b: Comparison of Impact of Scent on Customer Behavior across Stores and Cities (ANOVA)

Store Big Bazaar and City Vijayawada achieve the highest mean score (63.06). Significance value of Store (0.00) is less than the threshold value (0.05), it can be concluded that Store factor alone do affect consumer opinion on music. The significance value of City (0.00) and interaction between the two factors Store * City $(0.00)$ are less than the threshold value (0.05). These are leading to the conclusion that Store, City, Store * City does make a difference in consumer opinion on scent.

\section{B. Impact of Scent on Store Employee Behavior}

$\mathrm{H}_{0}$ - Scent in the retail store is not having positive impact on the store employee behavior

An attempt was made to extract the opinion of the store employees about the impact of scent on their behavior at organized retail stores. Four options, about scents that normally influence behavior of employees were asked to respondents. The results are presented in table: 7.3. The mean values of the statements varied between 2.89 and 3.47. The statements 'Scents in the store contributes to pleasant work environment' secured the highest rating with a mean value of 3.47 and 69.48 per cent score respectively. The statement 'Suitable scents contribute to my job satisfaction and improved store loyalty', secured second position with a mean value of 3.30 and 66.07 per cent score respectively. The third preference has been given to the statement 'Scents in the store keeps me excited and active to be able to serve customers better' with a mean value of 3.23 and 64.67 per cent score. The statement 'Scents have a positive influence on my performance as a sales person' secured the least mean value 2.89 and 57.78 per cent score respectively. The standard deviation 0.25 signifies the consistency in respondents' opinion for the statements used in the question.

\begin{tabular}{|c|c|c|c|}
\hline Scent & Score & Mean & $\begin{array}{c}\% \text { to } \\
\text { Max. Score }\end{array}$ \\
\hline Scents in the store contributes to pleasant work environment & 938 & 3.47 & 69.48 \\
\hline Scents in the store keeps me excited and active to be able to serve customers better & 873 & 3.23 & 64.67 \\
\hline Scents have a positive influence on my performance as a sales person & 780 & 2.89 & 57.78 \\
\hline \multirow[t]{3}{*}{ Suitable scents contribute to my job satisfaction and improved store loyalty } & 892 & 3.30 & 66.07 \\
\hline & Group Mean & 3.23 & 64.50 \\
\hline & SD & 0.25 & \\
\hline
\end{tabular}

Table 2:- Impact of Scent on the Behavior of Employees in Organized Retail Stores Source: primary data

\section{Comparison of Impact of Scent on Employee Behavior between Male and Female}

The mean scores of gender wise responses on impact of Scent on employee behavior is given in the Table 2.1a followed by ANOVA Table 2.1b.

The mean scores of the sample respondents was found to be 55.50 indicating that the respondents have given considerably less importance to Scent. Further, the average scores for Male and Female are 58.62 and 48.57 respectively.

\begin{tabular}{|c|c|c|c|}
\hline Gender & $\mathrm{N}$ & Mean & Std. Deviation \\
\hline Male & 186 & 58.6290 & 16.81785 \\
Female & 84 & 48.5714 & 11.65703 \\
Total & 270 & 55.5000 & 16.06880 \\
\hline
\end{tabular}

Table 2.1a: Scent Impact across Gender of employees

Source: primary data 
ISSN No:-2456-2165

\begin{tabular}{|c|c|c|c|c|c|}
\hline Gender & Sum of Squares & Df & Mean Square & F & Sig. \\
\hline Between Groups & 5853.525 & 1 & 5853.525 & 24.664 & .000 \\
Within Groups & 63603.975 & 268 & 237.328 & & \\
Total & 69457.500 & 269 & & & \\
\hline
\end{tabular}

Table 2.1b: Comparison of Impact of Scent on Employee Behavior between Male and Female (ANOVA)

The Analysis of Variance (ANOVA) was conducted to find out whether there existed any significant difference between Male and Female in their average scores as expressed in the table 2.1a. The result of the ANOVA is given in Table 2.1b. The calculated $F$ value (24.66) was found to be significant at $5 \%$ level. The results indicated that there existed a significant variation in the perception of Male and Female employees towards impact of Scent on their behavior.
Comparison of Impact of Scent on Employee Behavior with respect to Age

The mean scores of age wise responses on impact of Scent on employee behavior is given in the Table 2.2a followed by ANOVA Table 2.2b.

The mean scores of the sample respondents was found to be 55.50 indicating that respondents have given considerably less importance to scent. The mean scores of Impact of scent on employee behavior were given in Table 2.2a for identified age groups 20-30, 31-45, 45 above. The average scores for respondents of age group 20-30 is 53.93, for the age group 31-45 is 54.93, and for the age group 45 above the average score is 59.16 respectively.

\begin{tabular}{|c|c|c|c|}
\hline Age & N & Mean & Std. Deviation \\
\hline $20-30$ & 127 & 53.9370 & 15.50256 \\
$31-45$ & 77 & 54.9351 & 14.76780 \\
$>45$ & 66 & 59.1667 & 18.13588 \\
Total & 270 & 55.5000 & 16.06880 \\
\hline
\end{tabular}

Table 2.2a: Scent Impact on employees of different age groups

Source: primary data

\begin{tabular}{|c|c|c|c|c|c|}
\hline Age & Sum of Squares & Df & Mean Square & F & Sig. \\
\hline Between Groups & 1222.162 & 2 & 611.081 & 2.391 & .093 \\
Within Groups & 68235.338 & 267 & 255.563 & \\
Total & 69457.500 & 269 & & \\
& & & & \\
\hline
\end{tabular}

Table 2.2b: Comparison of Impact of Scent on Employee Behavior among different age groups (ANOVA)

The Analysis of Variance (ANOVA) was conducted to find out whether there existed any significant difference among respondents of three age groups as expressed in the table 2.2a. The result of the ANOVA is given in Table 2.2b. The ANOVA result showed that the calculated $\mathrm{F}$ value (2.39) was found to be not significant at 5\% level. The results indicated that there exists no significant variation among employees of different age groups in their average scores on impact of scent on their behavior.
Comparison of Impact of Scent on Employee Behavior with respect to Educational Qualification

The mean scores of Educational qualification wise responses on impact of scent on employee behavior is given in the Table 2.3a followed by ANOVA Table 2.3b.

The mean scores of sample respondents was found to be 55.50 indicating that the respondents have given considerably less importance to scent. The average scores for respondents having SSC/Inter qualification is 52.97, for respondents of degree qualification the average score is 58.99, for respondents having post-graduation and above the average score is 53.20 respectively.

\begin{tabular}{|c|c|c|c|}
\hline Education & $\mathrm{N}$ & Mean & Std. Deviation \\
\hline ssc/inter & 47 & 52.9787 & 14.28208 \\
Degree & 109 & 58.9908 & 16.62188 \\
pg\&above & 114 & 53.2018 & 15.74306 \\
Total & 270 & 55.5000 & 16.06880 \\
\hline
\end{tabular}

Table 2.3a: Scent Impact on Employee Behavior based on Educational Qualification Source: primary data 
ISSN No:-2456-2165

\begin{tabular}{|c|c|c|c|c|c|}
\hline Education & Sum of Squares & Df & Mean Square & F & Sig. \\
\hline Between Groups & 2229.171 & 2 & 1114.585 & 4.427 & .013 \\
Within Groups & 67228.329 & 267 & 251.791 & & \\
Total & 69457.500 & 269 & & \\
\hline
\end{tabular}

Table 2.3b:- Comparison of Impact of Scent on Employee Behavior based on Educational Qualification (ANOVA)

The Analysis of Variance (ANOVA) was conducted to find out whether there existed any significant difference among respondents of three educational groups as expressed in the table 2.3a. The result of the ANOVA is given in Table 2.3b. The ANOVA result showed that the calculated $\mathrm{F}$ value (4.42) was found to be significant at $5 \%$ level. The results indicated that there exists a significant variation among employees of different educational groups in their average scores on impact of scent on their behavior.
Comparison of Impact of Scent on Employee Behavior with respect to Designation

The mean scores of designation wise responses on impact of scent on employee behavior is given in the Table 2.4a followed by ANOVA Table 2.4b.

The mean scores of the sample respondents was found to be 55.50 indicating that the respondents have given considerably less importance to scent. The average score for sales person was 57.18 , for floor manager the average score is 54.69 , for mall manager the average score is 52.17 , for employees with other designations the average score is 52.74 respectively.

\begin{tabular}{|c|c|c|c|}
\hline Designation & N & Mean & Std. Deviation \\
\hline Salesperson & 151 & 57.1854 & 16.66909 \\
Floor manager & 49 & 54.6939 & 15.39102 \\
Mall manager & 39 & 52.1795 & 15.25204 \\
Others & 31 & 52.7419 & 14.65371 \\
Total & 270 & 55.5000 & 16.06880 \\
\hline
\end{tabular}

Table 2.4a: Scent Impact on Employee Behavior based on Designation

Source: primary data

\begin{tabular}{|c|c|c|c|c|c|}
\hline Designation & Sum of Squares & Df & Mean Square & F & Sig. \\
\hline Between Groups & 1126.605 & 3 & 375.535 & 1.462 & .225 \\
Within Groups & 68330.895 & 266 & 256.883 & \\
Total & 69457.500 & 269 & & \\
\end{tabular}

Table 2.4b:- Comparison of Impact of Scent on Employee Behavior based on Designation (ANOVA)

The Analysis of Variance (ANOVA) was conducted to find out whether there existed any significant difference among employees with different designations as expressed in the table 2.4a. The result of the ANOVA is given in Table 2.4b. The ANOVA result showed that the calculated $\mathrm{F}$ value (1.46) was found to be not significant at 5\% level. The results indicated that there exists no significant variation among employees with different designations in their average scores on impact of scent on their behavior.
Comparison of Impact of Scent on Employee Behavior with respect to Experience

The mean scores of experience wise responses on impact of scent on customer shopping experience is given in the Table 2.5a followed by ANOVA Table 2.5b.

The mean scores of the sample respondents was found to be 55.50 indicating that the respondents have given considerably less importance to scent. The average score for respondents having less than 2 years' experience is 56.61, for respondents having experience more than 2 years and less than 5 years is 52.11 , for respondents having experience more than 5 years is 55.58 respectively.

\begin{tabular}{|c|c|c|c|}
\hline Overall Experience & $\mathrm{N}$ & Mean & Std. Deviation \\
\hline 1-2 years & 177 & 56.6102 & 15.70613 \\
2.1 5 years & 59 & 52.1186 & 14.71580 \\
5 years & 34 & 55.5882 & 19.53104 \\
Total & 270 & 55.5000 & 16.06880 \\
\hline
\end{tabular}

Table 2.5a:- Scent Impact on Employee Behavior based on Experience

Source: primary data 
ISSN No:-2456-2165

\begin{tabular}{|c|c|c|c|c|c|}
\hline Overall Experience & Sum of Squares & Df & Mean Square & F & Sig. \\
\hline Between Groups & 892.994 & 2 & 446.497 & 1.739 & .178 \\
Within Groups & 68564.506 & 267 & 256.796 & \\
Total & 69457.500 & 269 & & \\
\hline
\end{tabular}

Table 2.5b:- Comparison of Impact of Scent on Employee Behavior based on experience (ANOVA)

The Analysis of Variance (ANOVA) was conducted to find out whether there existed any significant difference among respondents with different experience as expressed in the table 2.5a. The result of the ANOVA is given in Table 2.5b. The ANOVA result showed that the calculated $\mathrm{F}$ value (1.73) was found to be not significant at 5\% level. The results indicated that there exists a significant variation among employees with different experience in their average scores on impact of scent on their behavior.
Though the findings of the study revealed significant differences on the identified categorical variables such as gender and education, no significant differences were identified across variables like age, designation and experience of the respondents. Hence, we accept the null hypothesis.

Comparison of Impact of Scent on the Behavior of Store Personnel between stores and Cities.

The mean scores of store wise responses with respect to region on impact of scent on store employees is given in Table 2.6a followed by ANOVA Table 2.6b.

\begin{tabular}{|c|c|c|c|c|}
\hline Store & City & Mean & Std. Deviation & $\mathrm{N}$ \\
\hline \multirow[t]{4}{*}{ Big Bazaar } & Hyderabad & 62.3333 & 13.55125 & 45 \\
\hline & Vijayawada & 59.7778 & 17.22035 & 45 \\
\hline & Visakhapatnam & 54.3333 & 18.35880 & 45 \\
\hline & Total & 58.8148 & 16.71990 & 135 \\
\hline \multirow[t]{4}{*}{ Spencer’s } & Hyderabad & 57.6667 & 17.76104 & 45 \\
\hline & Vijayawada & 52.0000 & 13.79229 & 45 \\
\hline & Visakhapatnam & 46.8889 & 9.72864 & 45 \\
\hline & Total & 52.1852 & 14.71885 & 135 \\
\hline \multirow[t]{4}{*}{ Total } & Hyderabad & 60.0000 & 15.88229 & 90 \\
\hline & Vijayawada & 55.8889 & 15.99821 & 90 \\
\hline & Visakhapatnam & 50.6111 & 15.08083 & 90 \\
\hline & Total & 55.5000 & 16.06880 & 270 \\
\hline
\end{tabular}

Table 2.6a:- Scent Impact on the Behavior of Store Personnel across Stores and Cities Source: primary data

The mean scores of Impact of scent on store employees with respect to Big Bazaar and Spencer's in the cities of Hyderabad, Vijayawada and Visakhapatnam were given in Table 2.6a. The impact of scent on employees at Big Bazaar is found to be more intense in Hyderabad followed by Vijayawada and Visakhapatnam with average scores 62.33, 59.77 and 54.33 respectively. The impact of scent on employees at Spencer's is found to be more intense in Hyderabad followed by Vijayawada and Visakhapatnam with average scores $57.66,52.00$ and 46.88 respectively.

\begin{tabular}{|c|c|c|c|c|c|}
\hline Source & $\begin{array}{c}\text { Type III Sum of } \\
\text { Squares }\end{array}$ & Df & Mean Square & F & Sig. \\
\hline Corrected Model & $7085.278^{\mathrm{a}}$ & 5 & 1417.056 & 5.998 & .000 \\
\hline Intercept & 831667.500 & 1 & 831667.500 & $3.520 \mathrm{E} 3$ & .000 \\
\hline Store & 2966.759 & 1 & 2966.759 & 12.557 & .000 \\
\hline City & 3987.222 & 2 & 1993.611 & 8.438 & .000 \\
\hline Store * City & 131.296 & 2 & 65.648 & .278 & .758 \\
\hline Error & 62372.222 & 264 & 236.258 & & \\
\hline Total & 901125.000 & 270 & & & \\
\hline Corrected Total & $69457.500 \quad$ a. R Squared = .102 (Adjusted R Squared = .085) \\
\hline \multicolumn{7}{|l|}{} \\
\hline
\end{tabular}

Table 2.6b: Comparison of Impact of Scent on the Behavior of Store Personnel across Stores and Cities (ANOVA) 
Store Big Bazaar and City Hyderabad achieve the highest mean score (62.33). Significance value of Store $(0.00)$ is less than the threshold value $(0.05)$, it can be concluded that Store factor alone do affect consumer opinion on scent. The significance value of City (0.00) is less than the threshold value $(0.05)$ and interaction between the two factors Store * City (0.75) is greater than the threshold value (0.05). These are leading to the conclusion that Store, City, Store * City does not make a difference in consumer opinion on scent.

\section{CONCLUSION AND IMPLICATIONS}

One person's sweet aroma is another's stench. A store's smell has to be powerful enough to lure in customers yet not offend neighboring businesses and landlords. The study revealed that scented environments generated more foot falls confirming the effect of aroma on organized retail customer behavior. However, the impact of scents on retail employee behavior is not found to be encouraging. Hence retailers need to diffuse aromas that would both attract customers towards the store and not irritate employees despite their longer stay with the store. Creating a relaxing and inviting environment will ensure that your customers will want to spend a longer time with you. The right ambient scenting solution can subtly prompt consumers to spend more time in retail environments or can be an effective means of drawing people into your store, while offering retail store personnel a happier work place.

\section{REFERENCES}

[1]. Ishwar kumar, et.al., Influence of retail atmospherics on customer value in an emerging market condition, Great Lakes Herald, Vol.4, No.1, pp.1-13, March 2010.

[2]. Hendrik N.J. Schifferstein, et.al, Can ambient scent enhance the nightlife experience? Chem. Percept., Vol.4, pp.55-64, 2011.

[3]. Tendai, $\mathrm{M}$ and Crispen, C., In-store shopping environment and impulsive buying, African Journal of Marketing Management, Vol.1, No.4, pp.102-108, 2009.

[4]. Jean-Charles Chebat and Richard Michon., Impact of ambient odors on mall shoppers' emotions, cognition and spending A test of competitive casual theories, Journal of Business Research, Vol.56, pp.529-539, 2003.

[5]. H. N. J. Schifferstein and S.T. Blok., The signal function of thematically (in) congruent ambient scents in a retail environment, Chem. Senses., Vol.27, pp. 539-549, 2002.

[6]. Spangenberg, E.R, et.al, Improving the store environment: Do olfactory cues affect evaluations and behaviors? Journal of Marketing, Vol.60, pp.67-80, April 1996. 